\title{
ФІЗІОЛОГІЧНІ МЕХАНІЗМИ ДІЇ ПОЛЯРИЗОВАНОГО СВІТЛА НА БІЛЬ
}

\author{
С. О. Ґуляр, 3. А. Тамарова \\ Інститут фрізіології ім. О. О. Богомольця НАН України \\ Інтернаціональний медичний інноваційний центр
}

\begin{abstract}
Наведено експериментальні докази дії поляризованого світла апарату БІОПТРОН на точку акупунктури і осередок болю. Доведено, що ПАЙлЕР-світло може викликати анальгезію, яка залежить від вибору зони аплікації, експозиції, характеру болю (гострий, тонічний або вісцеральний). Анальгетична реакція має загальний характер і супроводжується участю опіоідергічної противобольової системи.
\end{abstract}

Ключові слова: БІОпТРОН, поляризоване світло, біль, анальгезія, точка акупунктури.

\section{ФИЗИОЛОГИЧЕСКИЕ МЕХАНИЗМЫ ДЕЙСТВИЯ ПОЛЯРИЗОВАННОГО СВЕТА НА БОЛЬ}

\author{
С. А. Ґуляр, 3. А. Тамарова \\ Институт фозиологии им. А.А. Богомольца НАН Украины \\ Интернациональный медицинский инновационный центр
}

\begin{abstract}
Приведены экспериментальные доказательства действия поляризованного света аппарата БИоПТРОН на точку акупунктуры и очаг боли. Доказано, что ПАЙЛЕР-свет может вызывать анальгезию, которая зависит от выбора зоны аппликации, экспозиции и характера боли (острая, тоническая или висцеральная). Анальгетическая реакция имеет общий характер и сопровождается участием опиоидэргической противоболевой системы.
\end{abstract}

Ключевые слова: БИОПТРОН, поляризованный свет, боль, анальгезия, точка акупунктуры.

\section{PHYSIOLOGICAL MECHANISMS OF POLARIZED LIGHT INFLUENCE ON PAIN}

\author{
S. O. Gulyar, Z. A. Tamarova \\ Bogomoletz Institute of Physiology of National Academy of Sciences of Ukraine \\ International Medical Innovation Center
}

\begin{abstract}
There are presented experimental evidences of BIOPTRON device polarized light influence on the acupuncture points and pain locus. It is proved that PILER-light can induce analgesia which depends on the choice of the application zone, exposure and nature of pain (tonic, acute or visceral). Analgesic response has systemic character and is accompanied by participation of opioidergic nociceptive system
\end{abstract}

Key words: BIOPTRON, polarized light, pain, analgesia, acupuncture point.

Known analgesic effects of polarized light in humans have only a subjective confirmation. Quantitative assessment of pain without distorting influence of psychogenic factors is possible in experiments on laboratory animals. A promising factor for analgesia is low intensity polychromatic polarized light. We have previously found that changes in the functional state of organs and body systems can occur under the influence of electromagnetic fields of different frequencies, including visible range on acupuncture points and pathology focus $[1,3,5]$.

Purpose. To describe analgesic effect of polychromatic polarized light at tonic, and acute visceral pain and its possible mechanisms.

Material and methods. The effect of polarized light of BIOPTRON device (wavelength $480-3400 \mathrm{~nm}$,
95\% polarization of the incoherent, density power - $40 \mathrm{~mW} / \mathrm{cm} 2$ - PILER-light). In 250 of adult white male mice were created locus of tonic (formalin test), acute (electrical stimulation of the soles of the paws) and visceral pain (peritoneum chemical irritation:

(C) С. О. Іуляя, 3. А. Тамарова 
A

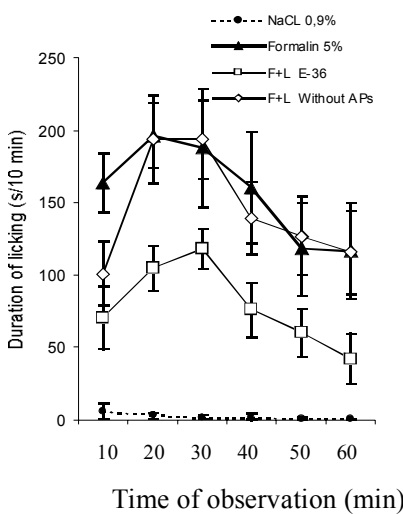

$\mathrm{B}$

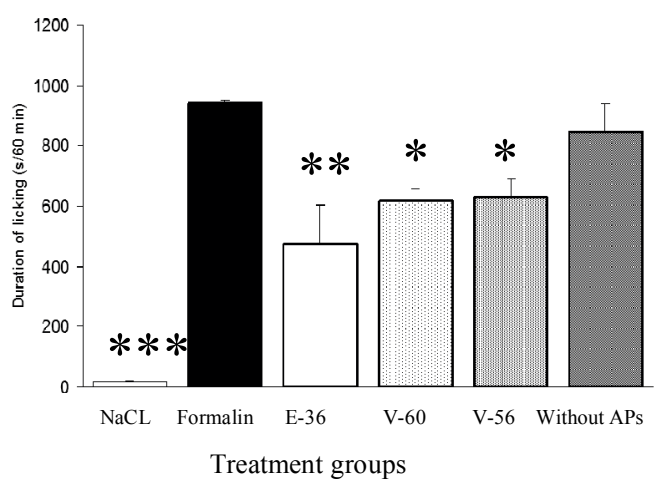

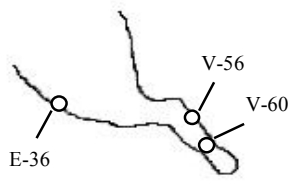

Lateral view

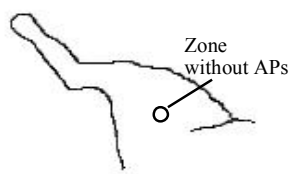

Medial view

Fig. 1. The mean ( \pm SEM) threshold of vocalization from electrical stimulation of feet for two groups of mice with (A) and without (B) exposure of acupoint E-36 to polarized light: Period when the mice were in the partial immobilization chamber is indicated with rectangles: gray for mice who received the light therapy sessions (A); white for mice in the control group (B)

A

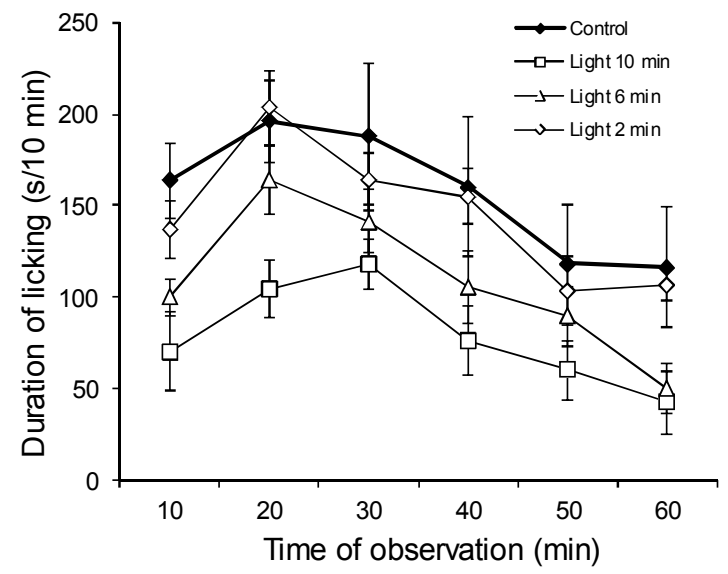

B

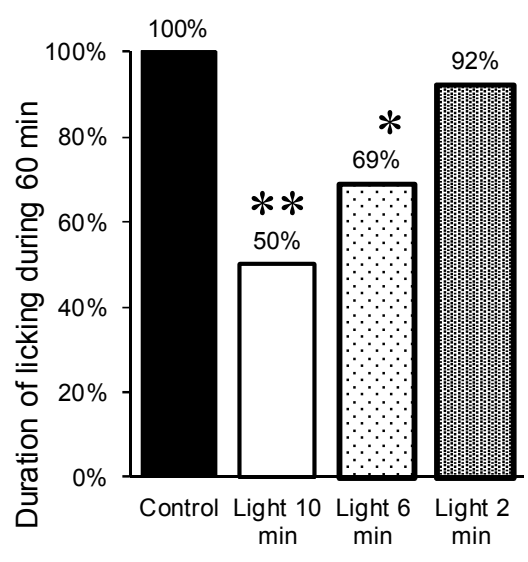

Fig. 2. Effect of polarized light on formalin-induced pain behavior in mice: A: Changes in formalin-induced nociceptive behavioral responses before and after exposure of AP E-36 or a skin area without any analgesic APs to polarized light. The mean ( $₫$ SEM) duration (s) of licking the painful area at 10 subsequent min. $\mathrm{F}+\mathrm{L}-$ the mice with formalin injection into the hind limb followed by light therapy. Comparison with $\mathrm{NaCl}$-evoked response. B: The mean ( $\pm \mathrm{SEM}$ ) duration

(s) of licking the painful area for 60 min of observation in six groups of mice, which received: 1) injection of $0.9 \%$ $\mathrm{NaCl}$ in hind limb; 2) injection of $5 \%$ formalin (attenuated in $0.9 \% \mathrm{NaCl}$ ) in hind limb; 3-6) injection of $5 \%$ formalin in hind limb followed by polarized light exposure of one AP (E-36, V-60, V-56) or of a skin area without any analgesic APs. Significant difference from the control (formalin): **** $\mathrm{P}<0.001,{ }^{* *} \mathrm{P}<0.01, * \mathrm{P}<0.05$. C: Localization of the zone exposed to polarized light 
Table 1

Duration ( $\mathrm{s} / 60 \mathrm{~min}$ of observation) of behavioral responses of mice with formalin-induced pain and different durations of exposure of acupoint E-36 to polarized light ( $M \pm m)$

\begin{tabular}{|c|c|c|c|c|}
\hline \multirow{2}{*}{$\begin{array}{c}\text { Behavioral } \\
\text { responses }\end{array}$} & \multirow{2}{*}{ Control } & \multicolumn{3}{|c|}{ Duration of exposure of AP E-36 to polarized light } \\
\hline & & $2 \mathrm{~min}$ & $6 \mathrm{~min}$ & $10 \mathrm{~min}$ \\
\hline Licking & $942,1 \pm 130,9$ & $\begin{array}{c}870,2 \pm 64,3 \\
t=0,49\end{array}$ & $\begin{array}{c}650,6 \pm 39,2 * \\
t=2,13\end{array}$ & $\begin{array}{c}471,3 \pm 38 * * \\
t=3,45\end{array}$ \\
\hline Sleeping & $557,3 \pm 130,6$ & $\begin{array}{c}629,4 \pm 161,2 \\
t=0,35\end{array}$ & $\begin{array}{c}869,4 \pm 176,5 \\
t=1,42\end{array}$ & $\begin{array}{c}1087,3 \pm 187,7 \text { * } \\
t=2,32\end{array}$ \\
\hline Running & $92,4 \pm 26,9$ & $\begin{array}{c}154,5 \pm 35,6 \\
t=1,39\end{array}$ & $\begin{array}{c}165,4 \pm 32,7 \\
t=0,59\end{array}$ & $\begin{array}{l}126 \pm 33 \\
t=0,79\end{array}$ \\
\hline Washing & $139,4 \pm 29,9$ & $\begin{array}{c}127,1 \pm 32,5 \\
t=0,28\end{array}$ & $\begin{array}{c}27,5 \pm 19,1 \\
t=1,43\end{array}$ & $\begin{array}{c}186,8 \pm 63,1 \\
t=0,68\end{array}$ \\
\hline Eating & $0,1 \pm 0,09$ & 0 & 2 & $\begin{array}{c}39,7 \pm 15,4 * \\
t=2,57\end{array}$ \\
\hline $\begin{array}{l}\text { Number of animals } \\
\text { eating (of } 10 \text { ) }\end{array}$ & 1 & 0 & & 6 \\
\hline
\end{tabular}

$* \mathrm{P}<0.05 ; * * \mathrm{P}<0.01$ compared to control (otherwise not significant).

intraperitoneally $2 \%$ solution of acetic acid and rectal mucosa: capsaicin). We evaluated pain and non-painful behavioral responses in response to a light application to the locus of pain or acupuncture points (AP).

Results. At tonic pain under the influence of polarized light on TA statistically true, suppressed pain behavioral response (BR) (licking the locus of pain), and increased the duration of non-painful BR (sleeping, eating) (fig. 1) [2, 4, 7].

The degree of analgesia also depended on the choice of the AP. Out of two-studied AP the more pronounced analgesic effect showed point E-36 [1, 6]. Action of light on the area of skin containing no analgesic AP proved ineffective. The degree of analgesia depended on the degree of exposure. Within the tested time intervals (4, 8, and $10 \mathrm{~min}$ ) maximum analgesia (50\%) was observed at the highest exposure (fig. 2, tabl. 1).

A single 10-minute PILER-light influence on AP E-36 caused a statistically significant increase of the pain threshold to electrical stimulation of the foot skin (acute pain) [8]. The threshold increased up to $34.2-59.1 \%$, the analgesic effect lasted more than 3 hours (fig. 3).

Thus, the analgesic effect PILER-light dependent on the exposure, whether it influenced on the locus of pain or analgesic AP, and on AP choice. This PILERanalgesia is not dependent on the application side (right, left, both sides) (fig. 4, tabl. 2), on whether the

Table 2

Duration (s/60 min of observation) of behavioral responses in mice with formalin-induced pain before and after 10 min polarized light exposure to acupoint $E-36$ of the left paw, right paw and both paws simultaneously $(\mathbf{M} \pm \mathbf{m})$

\begin{tabular}{|c|c|c|c|c|}
\hline \multirow{2}{*}{$\begin{array}{l}\text { Behavioral } \\
\text { responses }\end{array}$} & \multirow[b]{2}{*}{ Control } & \multicolumn{3}{|c|}{ Duration of exposure of AP E-36 to polarized light } \\
\hline & & Left hind limb & Right hind limb & $\begin{array}{c}\text { Left }+ \text { Right } \\
\text { hind limbs }\end{array}$ \\
\hline Licking & $942,1 \pm 130,9$ & $\begin{array}{c}471,3 \pm 38.0^{* * *} \\
t=3,45\end{array}$ & $\begin{array}{c}459,5 \pm 70,3^{* * *} \\
t=3,23\end{array}$ & $\begin{array}{c}535,6 \pm 70,5^{*} \\
t=2,73\end{array}$ \\
\hline Sleeping & $557,3 \pm 130,6$ & $\begin{array}{c}1087,3 \pm 187,7 * \\
t=2,32\end{array}$ & $\begin{array}{c}1560 \pm 124,3^{* * * *} \\
\mathrm{t}=5,56\end{array}$ & $\begin{array}{c}1147,0 \pm 168,5^{*} \\
t=2,77\end{array}$ \\
\hline Eating & $0,1 \pm 0,09$ & $\begin{array}{c}39,7 \pm 15,4 * \\
t=2,57\end{array}$ & $\begin{array}{c}5,8 \pm 5,8 \\
t=0,98\end{array}$ & $\begin{array}{c}126,7 \pm 71,6 \\
t=1,77\end{array}$ \\
\hline $\begin{array}{l}\text { Number of animals } \\
\text { eating (of } 10 \text { ) }\end{array}$ & 1 & 6 & 1 & 6 \\
\hline
\end{tabular}

$* \mathrm{P}<0.05 ; * * \mathrm{P}<0.01 ; * * * \mathrm{P}<0.001$ compared to control (otherwise not significant) 
A

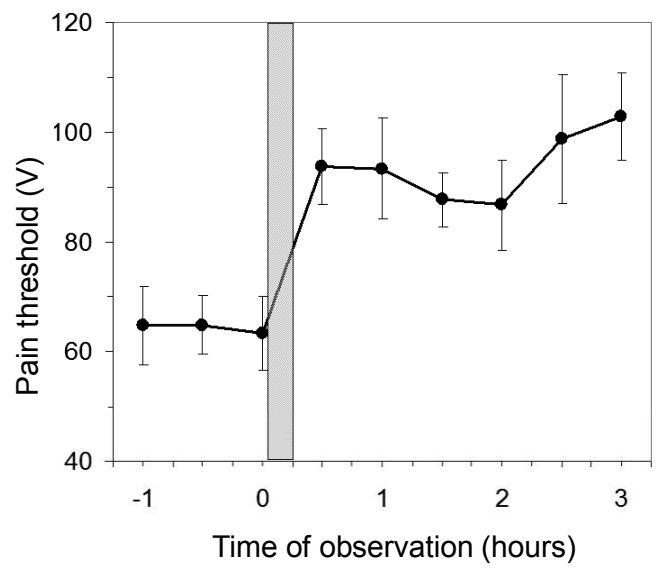

B

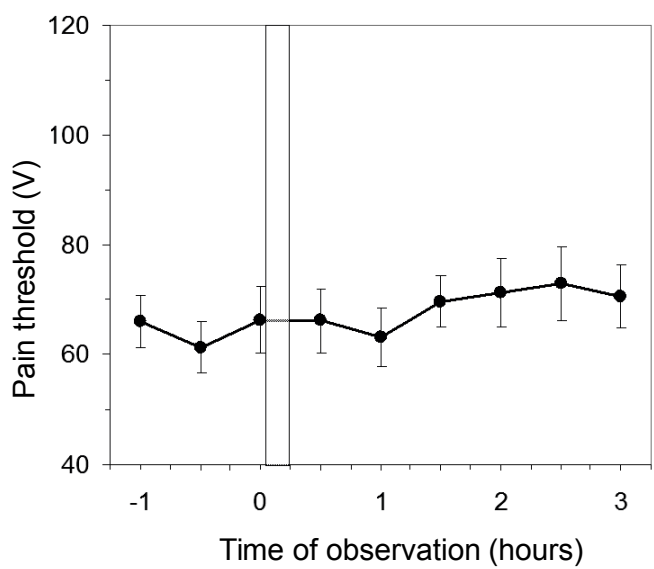

Fig. 3. Dependence of pain behavioral response on exposure of acupuncture point E-36 to polarized light: A: Mean $( \pm$ SEM) duration (s) of licking the painful area in sequential 10 min observation periods, in control and after 2, 6 or 10 min exposure of AP E-36 to polarized light. B: Mean duration of licking the painful area during the 60 min observation period (in \% of the control value) after different exposures to polarized light.

Significant difference from the control: ** $\mathrm{P}<0.01, * \mathrm{P}<0.05$

A

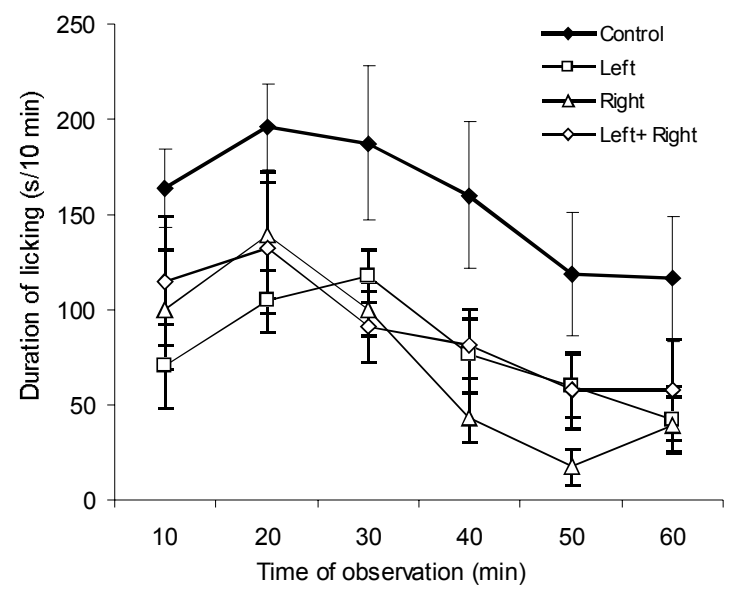

B

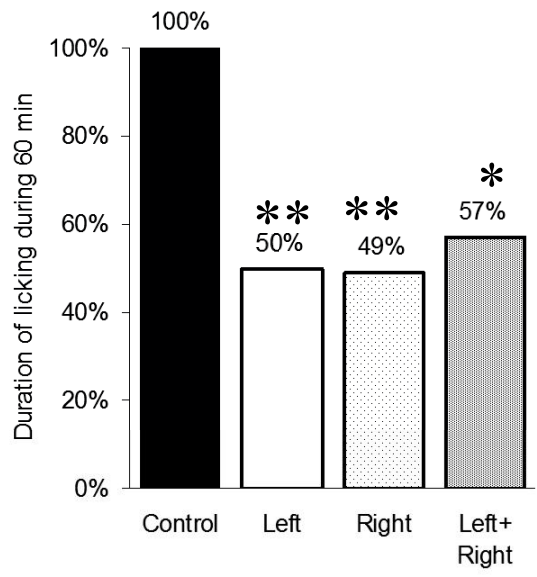

Fig. 4. Duration of licking the painful area after exposure of acupoint E-36 of the left paw, right paw or both paws to polarized light: A: Mean ( \pm SEM) duration (s) of licking the painful area in sequential 10 min observation periods for the control group (no light exposure) and three experimental groups (10 min exposure to polarized light of AP E-36 located on the left paw, right paw or both paws). B: Mean ( \pm SEM) duration (s) of licking the painful area for 60 min of observation

(\% of the control value) in the same groups as in A. Significant difference from the control: $* * \mathrm{P}<0.01$,

$$
\because \mathrm{P}<0.05
$$


application was after the onset of pain or pre-irrigation of pain by Oxyspray impact on AP zone.

PILER-light action on the area of the skin that did not contain analgesic AP or on all animals in general - did not cause statistically significant changes of the pain intensity. Thus, it revealed a high analgesic efficacy of white (polychromatic) PILER-light influence on analgesic AP.

For the first time there was a statistically significant attenuation of visceral pain under the action of PILERlight on AP [6, 9]. In animals that immediately after the injection of acetic acid were subjected to 10-minute PILER-light influence on one of the analgesic AP (E-36, E-43, VC-8, RP-6), there decreased the duration of pain and increased the non-painful behavioral responses. Comparing the total duration of pain in control and experimental animals, the greatest analgesic effect (76.5\%) gave AP E-43 and VC-8 (76.5\% and 76.3\%), followed by AP RP-6 $(46.8 \%)$ and E-36 (41.4\%). A similar result was obtained in case of light applications in the area of rectum after a preliminary application of capsaicin solution. It is concluded that the effect of PILER-light on AP or pain center can serve as a convenient nonpharmacological method of preventing visceral pain.

A comparative study of the PILER-light analgesic action effectiveness and pharmacotherapy showed that its 10-minute application on analgesic AP E-36 significantly enhances the analgesic effect of low doses of analgesics (analgin, tramal) [8]. This is shown in models of both acute and tonic pain. At tonic pain, analgin in a dose of $4.2 \mathrm{mg} / \mathrm{kg}$ reduced nociceptive behavioral responses for $28.5 \%$ and $0.8 \mathrm{mg} / \mathrm{kg}$ of tramal dose $-34.2 \%$. In case of combination (the same doses) with PILERlight analgesics (AP E-36), analgesia equaled 47.1\% and $50.7 \%$ respectively. Without PILER-light influence, to reach about the same level of analgesia, there required twice as large doses of analgesics. In the model of acute pain, after $4.2 \mathrm{mg} / \mathrm{kg}$ analgin injections, in combination with the PILER-light action on AP E-36, in 60 minutes the pain threshold reached $149 \%$. In 3 hours we observed the second wave of analgesia increase up to $157.3 \%$, and even, in the end of the study, (4 hours), the pain threshold was a half times higher (151.5\%) than normal. Under the tramal action, in combination with PILER-light, the pain threshold increased up to $148.4 \%$. At the end

References

1. Anthology of light therapy. Medical BIOPTRON technologies (theory, clinical application, prospects). Proceedings. Gulyar S.A., Editor-in-chief. Kyiv: Bogomoletz Institute of Physiology at the National Academy of Sciences of Ukraine and Shupyk National of the observation period ( 4 hours) the pain threshold in the group, which employed only tramal, was $121.7 \%$, and in combination of Tramal and PILER-light, it reached $141.6 \%$. The results allow us to conclude that BIOPTRON device light application at tonic and acute pain intensifies and prolongs low doses analgesics` analgesia effect.

While study of PILER-light mechanisms action, we revealed participation of opioidergic analgesic brain system in analgesic effect manifestation [10]. We used the above-described experimental models, at the background of pre-injection opiate receptor blocker - naloxone. We revealed a direct dependence of the degree of weakening of PILER-light analgesic action and naloxone dose.

PILER-light influence on the APE-36 in animals whom naloxone was preliminary injected, did not cause the pain threshold growth. We observed its significant growth in his case, the polarized light action on acupuncture points was done without naloxone prior injection.

These data suggest that the analgesic effects of PILERlight on the tonic and acute pain occur with the help of opioidergic brainstem. This fact is fan additional evidence of the body's electromagnetic balance system regulation, components of which are receptor (acupuncture points), nerve and out of nerve conductive and effector links (opioidergic brain system).

Conclusion. The fact of polarized light influence on acupuncture points is experimentally established. PILER-light analgesic efficacy while its application on the acupuncture points is revealed. Opioidergic brain system participates in its mechanism, which is realized through a functional way of electromagnetic energy transport through connective tissue. A possibility of creating analgesia by non-invasive method has practical significance. On this basis and taking into consideration metameric and propriovisceral relationships, there are developed treatment regimens. They include the influence by polychromatic polarized light on acupuncture points, in outside the nerve ways of electromagnetic signals and hearth pain to alleviate pain syndromes of the musculoskeletal, peripheral and visceral origin. Specific procedures of analgesic light therapy is given in the Manual on BIOPTRON-PILER-light application in medicine, 2006; 2011 [5].

Medical Academy of Postgraduate Education at the Ministry of Health of Ukraine; 2009 (in Ukrainian, Russian).

2. Gulyar S.A., Limansky Y.P., Tamarova Z.A. Analgesic effects of Bioptron PILER light. J. of practitioners. 1999; 4: 21-23 (in Russian). 
3. Gulyar S.A., Limansky Y.P. Biophysical basis of Bioptron light puncture and mechanisms of primary reception of electromagnetic waves of optical range. Akupunktura Polska. 2004; 30, 1: 1097-1123.

4. Gulyar S.A., Limansky Y.P., Tamarova Z.A. Suppression of pain by influence of BIOPTRONpolarized light on acupoints. European Journal of Pain / 5th Congress of the European Federation of IASP Chapters (EFIC), Istanbul, Sept. 13-16. 2006; 10, Suppl 1: S212.

5. Gulyar S.A., Kosakovsky A.L., eds. BIOPTRONPILERlight application in medicine. Kyiv: BIP NAS of Ukraine and SNMAPE of Ukraine; 2006; 2nd ed. 2011 (in Ukrainian, Russian).

6. Limansky Y.P., Tamarova Z.A., Gulyar S.A. Suppression of visceral pain by action of the low intensity polarized light on antinociceptive points of acupuncture. Fiziol.J. 2003; 49: 43-51 (in Ukrainian).

7. Limansky Y.P., Tamarova Z.A., Gulyar S.A. Suppression of pain by exposure of acupuncture points to polarized light. Pain Res. Manag. 2006, Spring; 11, 1: 49-57.
8. Limansky Y.P., Gulyar S.A., Tamarova Z.A. BIOPTRON-induced analgesia: 8 . Suppression of acute pain by combined action of PILER-light and low doses of analgetics. Anthology of light therapy. Proceedings. Kyiv: BIP NAS of Ukraine, 2009: 247254 (in Russian).

9. Limansky Y.P., Gulyar S.A., Tamarova Z.A. BIOPTRON-induced analgesia: 9 . Influence of the low intensity polarized light on visceral pain. Anthology of light therapy. Proceedings. Kyiv: BIP NAS of Ukraine, 2009: - C. 255-265 (in Russian).

10. Limansky Y.P., Gulyar S.A., Tamarova Z.A. BIOPTRON-induced analgesia: 10 . Involvment of opioid-ergic system in analgetic effect of polarized light on antinociceptive acupuncture points. Anthology of light therapy. Proceedings. Kyiv: BIP NAS of Ukraine, 2009: - C. 266-275 (in Russian). 